\title{
PENGARUH GOOD CORPORATE GOVERNANCE DAN INTELLECTUAL CAPITAL TERHADAP FINANCIAL PERFORMANCE \\ (Studi Empiris Pada Perusahaan Manufaktur Yang Terdaftar Di Bursa Efek Indonesia)
}

\author{
Indriyani Ningsih Sinurat ${ }^{1}$ \\ indrisinurat@gmail.com \\ Sylvia Christina Daat., SE., M.Sc, $\mathbf{A k}^{2}$ \\ Linda Y. Hutadjulu, SE., M.Si., Ak., $\mathrm{CA}^{3}$ \\ Jurusan Akuntansi, Fakultas Ekonomi dan Bisnis Universitas Cenderawasih
}

\begin{abstract}
This study aims to examine the influence of good corporate governance and intellectual capital to financial performance (financial performance). Corporate governance mechanisms in this research are managerial ownership, institutional ownership, and the proportion of independent commissioners. Intellectual capital is measured using Value Added Intellectual Capital (VAIC) model which has three components (physical capital, human capital and structural capital), and financial performance is measured by return on assets (ROA). Secondary data was used by derived from the financial statements of manufacturing companies listed on the Indonesia Stock Exchange 2014-2016. The sampling technique used purposive sampling method with multiple linear regression analysis tools. Prior the regression test, the classical assumption test is done first. The results show that managerial ownership, institutional ownership and independent commissioner's proportion have no effect on financial performance, while intellectual capital has an effect on financial performance. The conclusion of this research is that intellectual capital can be used to improve financial performance if company can measure accurately but corporate governance still not proven can improve company's financial performance.
\end{abstract}

Keyword $\quad$ : financial performance, good corporate governance, intellectual capital.

\section{PENDAHULUAN}

Perkembangan ekonomi saat ini telah tumbuh semakin pesat ditandai dengan berkembangnya teknologi informasi yang semakin cepat dan persaingan bisnis semakin ketat. Dalam persaingan bisnis saat ini menuntut setiap perusahaan untuk meningkatkan kinerja dan inovasi terhadap pengelolaan bisnis. Para pelaku bisnis juga semakin menyadari untuk meningkatkan kinerja perusahaan. Kinerja perusahaan merupakan gambaran tentang kondisi keuangan suatu perusahaan yang di analisis dengan alat analisis keuangan, sehingga dapat diketahui mengenai baik buruknya keadaan keuangan perusahaan yang mencerminkan prestasi kerja dalam periode tertentu. Suatu perusahaan dengan manajemen yang menerapkan sistem pengelolaan yang baik akan memberikan perlindungan dan jaminan hak kepada para stakeholdersnya. Penerapan prinsip-prinsip good corporate governance (GCG) berkaitan dengan cara mempengaruhi investor agar yakin dapat memberikan keuntungan. Penerapan Good Corporate Governance akan mencegah kesalahan dan kecurangan, membantu perusahaan agar dapat bertahan dalam menghadapi persaingan yang semakin

\footnotetext{
${ }^{1}$ Alumni Jurusan Akuntansi FEB Uncen

${ }^{2}$ Dosen Jurusan Akuntansi FEB Uncen

3 Dosen Jurusan Akuntansi FEB Uncen
} 
ketat, dan mendapatkan kepercayaan dari investor sehingga meningkatkan kinerja perusahaan. Selain tantangan dalam menerapkan Good Corporate Governance demi meningkatkan kinerja keuangan perusahaan, tantangan globalisasi dan teknologi informasi yang terus berkembang serta persaingan yang semakin ketat, menuntut setiap perusahaan untuk mengubah pola manajemennya yang semula berbasis tenaga kerja menjadi berbasis pengetahuan. Menurut Pratama \& Suputra (2015) Perubahan dari ekonomi yang berbasis ilmu pengetahuan dengan penerapan manajemen pengetahuan memicu tumbuhnya minat dalam pengungkapan intellectual capital.

Penelitian mengenai pengaruh GCG dan IC terhadap kinerja keuangan mulai banyak, diantara adalah penelitian menurut Murwaningsari (2009) menunjukkan GCG yang diproksikan dengan kepemilikan manajerial dan institusional mempunyai pengaruh terhadap kinerja perusahaan. Sedangkan hasil penelitian Ariantini et. al. (2017) menunjukan bahwa GCG tidak berpengaruh terhadap kinerja keuangan perusahaan. Beberapa penelitian dalam negeri mengenai Intellectual Capital sebelumnya dilakukan oleh Ulum, Ghozali, \& A (2008) adalah meneliti hubungan antara IC dengan kinerja perusahaan pada industri perbankan tahun 2004-2006. Hasil penelitian yang didapat bahwa terdapat pengaruh IC (VAIC ${ }^{\mathrm{TM}}$ ) pada kinerja keuangan perusahaan. Penelitian yang dilakukan oleh Pratama \& Suputra (2015) meneliti pengaruh Good Corporate Governance dan Intellectual Capital pada Return On Aset (ROA) dengan menggunakan data pada perusahaan perbankan tahun 2010-2012. Hasil analisis diketahui bahwa kepemilikan manajerial, proporsi komisaris independen, dan value added intellectual coefficient berpengaruh pada return on asset. Sedangkan kepemilikan institusional tidak berpengaruh terhadap return on asset. Ningrum (2012a) meneliti pengaruh intellectual capital dan corporate governance terhadap financial performance. Hasil analisis menunjukan bahwa intellectual capital yang diukur dengan VAIC dan komisaris independen berpengaruh terhadap kinerja keuangan. Kepemilikan institusional dan kepemilikan manajerial tidak berpengaruh terhadap kinerja keuangan. Namun berbeda dengan penelitian yang dilakukan oleh Ratnasari et al., (2016) pada perusahaan manufaktur yang listing di BEI tahun 2012-2014 diperoleh hasil yang berbeda, yaitu IC tidak berpengaruh terhadap kinerja perusahaan.

Berdasarkan penelitian-penelitian yang telah dilakukan, menunjukan adanya ketidakkonsistenan tetapi bukti empiris tersebut dapat menunjukkan pentingnya penerapan Good Corporate Governance dan Intellectual Capital dalam mendukung pencapaian tujuan perusahaan dan dasar pengambilan kebijakan sehingga memberikan keuntungan kepada berbagai pihak - pihak yang berkepentingan (stakeholder dan shareholder) secara menyeluruh.

Terdapat alasan mengapa penelitian mengenai intellectual capital dan Good Corporate Governance perlu dilakukan menurut Ningrum (2012b), yaitu karena pengungkapan intellectual capital diperlukan dalam menentukan value perusahaan. Masuknya perusahaan-perusahaan asing ke pasar Indonesia menuntut perusahaan dalam negeri untuk semakin memperbaiki nilai (value) dan kinerja (performance) perusahaannya guna menghadapi persaingan yang semakin ketat. Sedangkan Good Corporate Governance berperan mengendalikan suatu perusahaan agar kegiatan operasinya berjalan sesuai apa yang diharapkan oleh stakeholders atau pihak yang berkepentingan. Keseimbangan kepentingan dari dua belah pihak yaitu pemegang saham selaku pemilik dengan manajemen adalah tujuan yang diharapkan dari penerapan corporate governance. Dengan adanya unsur Intellectual Capital dan Good Corporate Governance ,dapat menjadi pertimbangan stakeholder dalam menilai kinerja perusahaan.

Penelitian ini menggunakan sampel perusahaan manufaktur yang terdaftar di BEI. Pemilihan sektor manufaktur sebagai sampel penelitian dilandasi karena sektor industri ini merupakan salah satu ujung tombak dalam pembangunan suatu negara. Hal ini dikarenakan sektor ini memiliki keunggulan, seperti besarnya kapitalisasi modal yang tertanam, penyerapan tenaga kerja yang besar serta memiliki 
kemampuan dalam menciptakan nilai tambah dari setiap input yang diolah Sari \& Priyadi (2017). Perusahaan manufaktur identik dengan pabrik yang mengaplikasikan mesin, peralatan, teknik rekayasa dan tenaga kerja. Perusahaan manufaktur merupakan perusahaan berskala besar dan memiliki tingkat persaingan industri yang tinggi. Dengan tingkat persaingan industri yang tinggi, maka perusahaan membutuhkan suatu keunggulan kompetitif sehingga dapat bersaing dengan perusahaan lainnya.

Oleh karena itu, perumusan masalah dalam penelitian ini adalah 1). Apakah kepemilikan manajeriam berpengaruh terhadap kinerja keuangan ?, 2). Apakah kepemilikan institusional berpengaruh terhadap kinerja keuangan ?, 3). Apakah proporsi komisaris independen berpengaruh terhadap kinerja keuangan ?, 4). Apakah intellectual capital berpengaruh terhadap kinerja keuangan ?. Dengan tujuan penelitian ini adalah untuk mengetahui pengaruh kepemilikan manajerial terhadap kinerja keuangan, untuk mengetahui pengaruh kepemilikan institusional terhadap kinerja keuangan, untuk mengetahui pengaruh proporsi komisaris independen terhadap kinerja keuangan, untuk mengetahui pengaruh intellectual capital terhadap kinerja keuangan

\section{TINJAUAN PUSTAKA}

\subsection{Agency Theory}

Sari \& Priyadi (2017) menyatakan bahwa Agency theory adalah teori yang menjelaskan hubungan antara principals (pemilik modal) dan agent (manajemen). Terdapat tiga asumsi sifat dasar manusia yang menjelaskan tentang teori agensi, yaitu : (1) Manusia pada umumnya mementingkan diri sendiri (self interest) ; (2) Manusia memiliki daya pikir terbatas mengenai persepsi masa mendatang (bounded rationality); (3) Manusia selalu menghindari resiko (risk averse).

Agency theory berkaitan dengan penyelesaian masalah yang timbul dalam hubungan keagenan yaitu principals (pemilik modal) dan agent (manajemen). Masalah ini timbul karena ketika terjadi konflik kepentingan (conflict of interest) antara pemilik dengan agen. Akan tetapi meski terjadi konflik kepentingan antara pemilik dan agen, masing-masing pihak harus dapat berkomitmen sesuai dengan kontrak yang telah disepakati. Kontrak antara pemilik dan agen merupakan motivasi bagi masing-masing pihak untuk melakukan kinerjanya.

Perusahaan sekarang ini telah memisahkan kepemilikan dan kontrol manajerial, dan tidak semua anggota di manajemen tingkat tinggi adalah pemilik perusahaan. Dalam pemisahan ini, tidak dapat terhindarkan terjadinya masalah keagenan. Akibatnya, menjadi tugas manajer perusahaan dan kepentingan bagi seluruh stakeholder untuk meminimalisir konflik kepentingan Yi Lin dalam Tertius \& Christiawan (2015). Menurut Nuswandari dalam Sari \& Priyadi (2017) keberadaaan dua kubu tersebut dapat menimbulkan permasalahan tentang mekanisme yang harus dibentuk untuk menyelaraskan kepentingan yang berbeda diantara keduanya. Sehingga dibangunlah corporate governance sebagai efektivitas mekanisme yang bertujuan meminimalisasi konflik keagenan. Dengan meminimalkan konflik kepentingan yang terjadi, diharapkan agen dapat bertindak sesuai dengan kepentingan pemilik yaitu meningkatkan return perusahaan sehingga kinerja perusahaan meningkat.

\subsection{Resources Based Theory}

Resources based theory, pada dasarnya merupakan teori yang membahas mengenai sumber daya yang dimiliki perusahaan serta kemampuan perusahaan dalam mengelola dan memanfaatkan sumber daya tersebut dengan baik, sehingga perusahaan dapat memperoleh keunggulan kompetitif secara berkesinambungan. Sumber daya intelektual termasuk di dalamnya, baik itu karyawan human capital, aset fisik physical capital maupun structural capital. Semakin baik pemanfaatan modal intelektual oleh perusahaan maka dapat menambah nilai suatu perusahaan serta dapat meningkatkan 
kinerja yang semakin baik pula dalam perusahaan yang kemudian berimbas pada pemuasan kepentingan yang dimiliki oleh para stakeholder perusahaan.

\subsection{Good Corporate Governance (GCG)}

Pengertian GCG adalah satu set hubungan antara manajemen perusahaan, dewan, pemegang saham, dan pemangku kepentingan lainnya OECD, 2004 dalam Tertius \& Christiawan (2015). GCG pada dasarnya berkaitan dengan cara semua pemangku kepentingan (stakeholder) berusaha untuk memastikan bahwa para manajer dan karyawan internal lainnya selalu mengambil langkah-langkah yang tepat atau mengadopsi mekanisme yang melindungi kepentingan stakeholder Al-Haddad et al., dalam Tertius \& Christiawan (2015). Selain itu, GCG juga menetapkan bagaimana berbagai pemegang saham dan pemangku kepentingan, manajemen, dan dewan direksi berinteraksi dalam menentukan arah dan kinerja perusahaan. Tujuan utama dari GCG adalah untuk menciptakan sistem pengendaliaan dan keseimbangan (check and balances) untuk mencegah penyalahgunaan dari sumber daya perusahaan dan tetap mendorong terjadinya pertumbuhan perusahaan. GGC yang baik harus memberikan insentif yang tepat bagi dewan dan manajemen untuk mengejar tujuan-tujuan bagi kepentingan perusahaan dan pemegang sahamnya serta memfasilitasi pengawasan yang efektif. Berikut ini beberapa hal yang berkaitan dengan good corporate governance;

\section{Kepemilikan Manajerial}

Kepemilikan manajemen didefinisikan sebagai persentase saham yang dimiliki manajemen yang secara aktif ikut dalam pengambilan keputusan perusahaan yang meliputi komisaris dan direksi. Manajer yang juga sekaligus sebagai pemegang saham dan manajer yang tidak sebagai pemegang saham akan memiliki motivasi yang berbeda (Ningrum, 2012b). Menurut Wahidahwati dalam Sari \& Priyadi (2017) kepemilikan manajerial merupakan pemegang saham dari pihak manajemen (Direksi dan Komisaris) yang secara aktif ikut dalam pengambilan keputusan perusahaan. Salah satu prinsip corporate governance yang penting adalah transparansi atau keterbukaan. Transparansi sulit dilakukan bilamana manajemen memiliki kepentingan dan informasi privat yang mendukung kepentingannya. Hal tersebut dimungkinkan tidak akan terjadi jika manajemen diposisikan sama sebagai pemilik perusahaan, tidak lagi hanya sebatas pengelola perusahaan. Besar kecilnya kepemilikan saham manajerial di perusahaan menandakan adanya kesamaan kepentingan antara manajemen dan pemegang saham serta dapat menjadi cara untuk mengurangi konflik keagenan yang terjadi dalam perusahaan.

2. Kepemilikan Institusional

Kepemilikan institusional (institutional ownership) merupakan kepemilikan saham oleh institusi atau lembaga seperti pemerintah, bank, asuransi, perusahaan investasi maupun kepemilikan institusi lain. Keberadaan investor institusional dianggap mampu menjadi mekanisme pengawasan yang efektif dalam setiap keputusan yang diambil oleh manajer. Hal tersebut disebabkan karena investor instiusional terlibat dalam pengambilan keputusan yang strategis sehingga tidak mudah percaya terhadap tindakan manipulasi laba perusahaan. Semakin besar kepemilikan institusional maka semakin efisien pemanfaatan aktiva perusahaan.

3. Komisaris Independen

Menurut (Undang-Undang No.40, 2007) anggaran dasar perseroan dapat mengatur adanya 1 (satu) orang atau lebih Komisaris Independen. Komisaris independen adalah anggota dewan komisaris yang tidak memiliki hubungan keuangan, hubungan kepengurusan, hubungan kepemilikan saham, dan/atau hubungan keluarga lainnya dengan anggota dewan komisaris 
lainnya, direksi dan/atau pemegang saham pengendali atau hubungan dengan bank, yang dapat mempengaruhi kemampuannya untuk bertindak independen.

\subsection{Intellectual Capital}

Menurut Wijaya (2017) Intellectual Capital (IC) merupakan salah satu sumber daya yang dimiliki oleh perusahaan. Intellectual capital (IC) biasanya didefinisikan sebagai perbedaan antara nilai pasar perusahan dan nilai buku pada perusahaan tersebut atau dari financial capital perusahaan tersebut. Intellectual capital (IC) seringkali menjadi faktor penentu utama perolehan laba suatu perusahaan.

Menurut Kartika \& Hatane (2011) intellectual capital merupakan aset utama suatu perusahaan disamping aset fisik dan finansial. Maka dalam mengelola aset fisik dan finansial dibutuhkan kemampuan yang handal dari intellectual capital itu sendiri, disamping dalam menghasilkan suatu produk yang bernilai diperlukan kemampuan dan daya pikir dari karyawan, sekaligus bagaimana mengelola organisasi dan menjalin hubungan dengan pihak eksternal.

Menurut Santosa dan Setiawan dalam Kartika \& Hatane (2011) Intellectual capital (IC) memiliki peran yang sangat penting dan strategis di perusahaan dalam mengukur sumber daya manusia didalamnya. Dalam akuntansi, IC dikategorikan dalam aset tidak berwujud (intangible asset). IC merupakan intangible asset yang sangat penting di era informasi dan pengetahuan, dimana IC mengacu kepada pengetahuan dan kemampuan yang dimiliki oleh suatu kolektivitas sosial, seperti organisasi, komunitas intelektual atau praktek profesional. IC merupakan pengetahuan yang dapat memberi manfaat bagi perusahaan. Manfaat tersebut berarti pengetahuan ini mampu menyumbangkan sesuatu atau memberikan kontribusi yang dapat memberikan nilai tambah dan kegunaan berbeda bagi perusahaan. Berbeda berarti pengetahuan tersebut merupakan salah satu indentifikasi yang membedakan suatu perusahaan dengan perusahaan lain.

\subsection{Kinerja Keuangan}

Kinerja keuangan perusahaan merupakan penentuan ukuran-ukuran tertentu yang dapat mengukur keberhasilan suatu perusahaan dalam menghasilkan laba. Kinerja keuangan merupakan salah satu faktor yang menunjukkan efektifitas dan efisien suatu organisasi dalam rangka mencapai tujuannya. Tujuan perusahaan akan sulit tercapai bila perusahaan tersebut tidak bekerja secara efisien, sehingga perusahaan tidak mampu baik langsung maupun tidak langsung bersaing dengan perusahaan sejenis Wijaya (2017).

Kinerja perusahaan dapat diukur dengan menggunakan rasio keuangan. Kinerja Keuangan dalam penelitian ini diukur dengan menggunakan rasio profitabilitas yaitu return on assets (ROA). Para investor sebelum melakukan penanaman modal salah satunya akan melihat rasio profitabilitas seperti ROA. Rasio profitabilitas yang digunakan dalam penelitian ini menggunakan Return on Asset (ROA) karena dapat memberikan gambaran tingkat pengembalian keuntungan yang dapat diperoleh investor atas investasinya (Prasinta, 2012) dalam Tertius \& Christiawan (2015) .

\subsection{Penelitian Terdahulu dan Pengembangan Hipotesis \\ 2.6.1 Pengaruh Kepemilikan Manajerial Terhdap Kinerja Keuangan}

Dengan adanya kepemilikan bagi manajemen, akan meningkatkan motivasi manajemen untuk bekerja dengan lebih baik dalam meningkatkan kinerja perusahaan. Manajemen akan lebih berhatihati dalam mengambil keputusan agar tidak merugikan perusahaan. Semakin besar kepemilikan manajer, maka manajer akan berusaha maksimal untuk meningkatkan laba perusahaan (alignment of interest) karena manajer memiliki bagian atas laba yang diperoleh (Jensen \& Meckling, 1976) dalam Tertius \& Christiawan (2015). 
Dengan demikian, kepentingan antara agen dan pemilik akan sejalan yaitu meningkatkan return perusahaan (ROA). Hal tersebut didukung oleh penelitian yang dilakukan El-chaarani (2014) yang mengukur internal ownership berdasarkan kepemilikan manajer, menghasilkan bahwa internal ownership berpengaruh positif dan signifikan terhadap kinerja keuangan. Kepemilikan manajer dalam penelitian tersebut, merupakan faktor penting yang mempengaruhi GCG dan kinerja perusahaan El-chaarani (2014). Penelitian Ratnasari et al., (2016) juga membuktikan bahwa kepemilikan manajerial berpengaruh terhadap return on asset. Maka diajukan hipotesis sebagai berikut:

\section{$H 1$ : Kepemilikan manajerial berpengaruh terhadap kinerja keuangan}

\subsubsection{Pengaruh Kepemilikan Institusional Terhadap Kinerja Keuangan}

Kepemilikan Institusional memiliki peran dalam mengontrol manajemen untuk tidak melakukan kegiatan-kegiatan yang merugikan pemilik saham. Pengawasan oleh investor institusional memicu manajemen untuk dapat memanfaatkan aset perusahaan secara efisien dan mencegah pemborosan. Hal tersebut menciptakan peningkatkan kinerja keuangan perusahaan dan mengurangi tindakan mementingkan diri sendiri. Oleh karena itu, dapat diasumsikan bahwa semakin tinggi presentase kepemilikan saham yang dimiliki oleh institusi (Kepemilikan institusional) akan menciptakan tingkat pengawasan lebih efektif dan semakin meningkatkan Kinerja keuangan perusahaaan.

Herawaty (2007) dalam Andreawan (2013) menyatakan bahwa kepemilikan institusional yang tinggi akan meningkatkan pengelolaan laba tetapi jika pengelolaan laba yang dilakukan perusahaan bersifat oportunis maka kepemilikan institusional yang tinggi akan mengurangi earnings management sehingga dapat meningkat kinerja keuangan perusahaan. Noviawan \& Septiani (2013) membuktikan bahwa kepemilikan institusional berpengaruh terhadap kinerja keuangan. Maka diajukan hipotesis sebagai berikut:

\section{H2 : Kepemilikan institusional berpengaruh terhadap kinerja keuangan}

\subsubsection{Pengaruh Komisaris Independen Terhadap Kinerja Keuangan}

Komisaris independen merupakan pihak yang tidak terafiliasi dengan perusahaan. Dengan kebenaran dan kelayakan informasi keuangan dan informasi perusahaan lainnya maka dapat membantu manajemen dalam pengambilan keputusan untuk meningkatkan kinerja perusahaan. Komisaris independen melakukan peran pengendali dalam mengevaluasi keputusan manajer melalui keterampilan mereka, keahlian pengetahuan dan objektivitas untuk mengurangi biaya agensi dan mengutamakan kepentingan pemegang saham. Komisaris independen diharapkan untuk bertanggung jawab untuk membawa penilaian independen untuk menanggung pada masalah strategi, kinerja dan sumber daya termasuk janji kunci dan standar perilaku (Pandya, 2011) dalam Tertius \& Christiawan (2015). Adanya komisaris independen diharapkan dapat mengurangi konsumsi manajer dan semakin banyaknya komisaris independen dapat memonitor perusahaan dengan lebih dekat, dan melakukan tindakan terkait dengan tata kelola perusahaan yaitu mengurangi manajemen puncak yang memiliki kinerja buruk. Dengan pemecatan manajemen puncak yang memiliki kinerja buruk tersebut, pasar merespon positif sehingga ROA meningkat.

Hal ini didukung dengan penelitian yang dilakukan oleh Brown \& Caylor (2004) dan Elchaarani (2014) ditemukan hubungan yang positif dan kuat antara independent board dengan kinerja perusahaan. Semakin besar jumlah komisaris independen dalam perusahaan menyebabkan manajemen perusahaan tidak dapat melakukan kecurangan sehingga kinerja perusahaan bagus dan sehat. Penelitian yang dilakukan oleh El-chaarani (2014) ditemukan bahwa proportion of independent director secara signifikan mempengaruhi kinerja perusahaan. Penelitian lain yang dilakukan oleh 
Pratama \& Suputra (2015) hasil penelitian menyatakan bahwa proporsi komisaris independen berpengaruh pada ROA perusahaan. Hal ini menunjukkan bahwa semakin banyak komisaris independen dalam perusahaan dapat menjalankan sistem pengawasan yang lebih baik pada manajemen dalam melakukan tugasnya, sehingga dapat membantu meningkatkan kinerja perusahaan. Maka dapat diajukan hipotesis sebagai berikut:

\section{H3 : Proporsi komisaris independen berpengaruh terhadap kinerja keuangan}

\subsubsection{Pengaruah Intellectual Capital Terhadap Kinerja Keuangan}

Sesuai dengan Resource Based Theory dimana perusahaan yang mampu mengelola intellectual capital dengan baik maka perusahaan tersebut akan memiliki keunggulan kompetitif serta diyakini mampu menciptakan nilai tambah yang berpengaruh terhadap peningkatan kinerja keuangan perusahaan. Menurut Barney dalam Faza \& Hidayah (2014) Intellectual capital diakui sebagai aset perusahaan karena mampu menghasilkan keunggulan kompetitif dan kinerja keuangan yang superior.

Semakin baik perusahaan dalam mengelola ketiga komponen intellectual capital, menunjukkan semakin baik perusahaan dalam mengelola aset. Jika perusahaan dapat memproduksi barang sesuai dengan kebutuhan konsumen, memberikan servis yang memuaskan dan menjaga hubungan baik dengan konsumen, maka hal itu adalah keunggulan kompetitif yang dimiliki perusahaan. Perusahaan yang memiliki keunggulan kompetitif akan dapat bersaing dan bertahan di lingkungan bisnis yang berkembang pesat. Pengelolaan aset yang baik dapat meningkatkan laba atas sejumlah aset yang dimiliki perusahaan yang diukur dengan return on Asset (ROA).

Penelitian Ningrum (2012b) membuktikan bahwa intellectual capital yang diukur dengan VAIC berpengaruh signifikan positif terhadap kinerja keuangan. Agustina et al., (2015), Widiatmoko (2015) juga membuktikan bahwa intellectual capital berpengaruh signifikan terhadap profitabilitas ROA. Dengan demikian dapat dijelaskan bahwa jika perusahaan dapat mengelola, memanfaatkan serta mengembangkan intellectual capital yang dimiliki, maka ROA akan meningkat pula.

Berdasarkan teori dan hasil penelitian terdahulu maka hipotesis yang diajukan adalah sebagai berikut

\section{H4 : Intellectual capital berpengaruh terhadap kinerja keuangan}

\subsection{Model Penelitian}

Model penelitian mengenai hubungan antar variabel-variabel yaitu kepemilikan manajerial, kepemilikan institusional, komisaris independen, intellectual capital, dan kinerja keuangan perusahaan yang telah dijelaskan, dapat digambarkan sebagai berikut :

\section{Gambar 1}

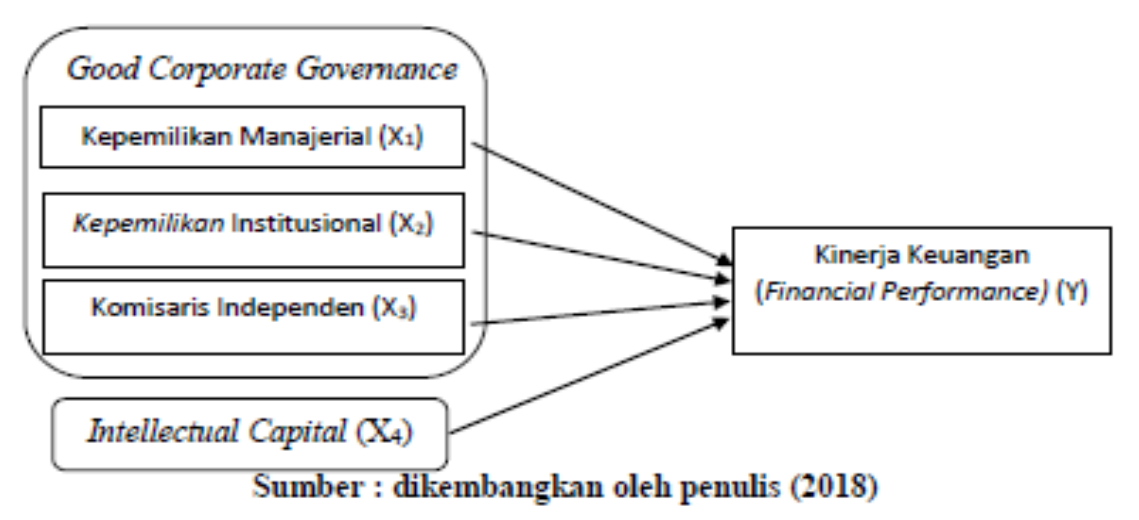




\section{METODE PENELITIAN}

\subsection{Jenis Penelitian}

Penelitian ini merupakan penelitian kausal komparatif (causal comparative research) yaitu tipe penelitian dengan tujuan untuk menyelidiki kemungkinan hubungan sebab-akibat dengan cara berdasar atas pengamatan terhadap akibat yang ada atau mencari faktor yang mungkin menjadi penyebab melalui data tertentu. Penelitian ini menjelaskan dan menggambarkan pengaruh Good Corporate Governance (Kepemilikan Manajerial, Kepemilikan Institusional, dan Proporsi Komisaris Independen) dan Intellectual Capital terhadap Financial Performance (Kinerja Keuangan).

\subsection{Populasi dan Sampel Penelitian}

Populasi dalam penelitian ini adalah seluruh perusahaan manufaktur yang terdaftar di Bursa Efek Indonesia (BEI) periode 2014-2016. Pada penelitian ini, metode pengambilan sampel menggunakan metode purposive sampling. Purposive sampling adalah metode pengambilan sampel dari populasi berdasarkan kriteria tertentu. Adapun kriteria-kriteria yang akan dijadikan sampel adalah sebagai berikut :

1. Perusahaan manufaktur yang terdaftar di Bursa Efek Indonesia periode 2014-2016

2. Perusahaan manufaktur yang mempublikasikan laporan tahunan (annual report) dan laporan keuangan secara berturut-turut periode 2014-2016

3. Perusahaan manufaktur yang menerbitkan laporan keuangan dengan menggunakan mata uang rupiah periode 2014-2016

4. Perusahaan manufaktur yang tidak mengalami kerugian selama tahun 2014-2016

5. Perusahaan manufaktur yang memiliki data terkait dengan penelitian selama tahun 2014-2016.

\subsection{Jenis Dan Sumber Data}

Jenis data yang digunakan merupakan data kuantitatif. Metode penelitian kuantitatif yaitu metode penelitian yang berlandaskan pada filsafat positivisme, digunakan untuk meneliti pada populasi atau sampel tertentu, teknik pengambilan sampel pada umumunya dilakukan secara random, pengumpulan data menggunakan instrumen penelitian, analisis data bersifat kuantitatif/statistik dengan tujuan untuk menguji hipotesis yang telah ditetapkan.

Sumber data yang digunakan dalam penelitian ini adalah data sekunder, yaitu sumber data penelitian diperoleh peneliti secara tidak langsung (melalui media perantara). Data sekunder dalam penelitian ini adalah perusahaan manufaktur yang terdaftar di Bursa Efek Indonesia (BEI) berupa annual report dan laporan keuangan (auditan) perusahaan yang dipublikasikan, periode 2014-2016.

\subsection{Definisi Operasional}

\subsubsection{Variabel Dependen}

Variabel dependen dalam penelitian ini adalah kinerja keuangan (financial performance), menggunakan proksi profitabilitas return on assets (ROA). ROA lebih dipilih daripada return on equity (ROE) karena total ekuitas yang merupakan denominator ROE adalah salah satu komponen dari VACA. Jika menggunakan ROE, maka akan terjadi double counting atas akun yang sama (yaitu ekuitas), dimana VACA (yang dibangun dari akun ekuitas dan laba bersih) sebagai variabel independen dan ROE (yang juga dibangun dari akun ekuitas dan laba bersih) menjadi variabel dependen. ROA diformulasikan sebagai berikut:

$$
\text { ROA }=\frac{\text { Laba Bersih }}{\text { Total Aset }}
$$




\subsubsection{Variabel Independen}

Variabel bebas merupakan variabel yang mempengaruhi variabel terikat. Variabel bebas dalam penelitian ini adalah kepemilikan manajerial, kepemilikan institusional, komisaris independen dan intellectual capital.

\section{Kepemilikan Manajerial}

Kepemilikan manajerial adalah jumlah kepemilikan saham yang dimiliki oleh pemilik, dewan eksekutif, dan manajemen dalam suatu perusahaan Tertius \& Christiawan (2015). Kepemilikan manajerial diformulasikan sebagai berikut :

$$
\text { Kepemilikan Manajerial }=\frac{\text { Jumlah Saham yang dimiliki Manajemen }}{\text { Jumlah Saham yang diterbitkan }}
$$

\section{Kepemilikan Institusional}

Kepemilikan institusional (institutional ownership) merupakan kepemilikan saham oleh institusi atau lembaga seperti pemerintah, bank, asuransi, perusahaan investasi maupun kepemilikan institusi lain. Kepemilikan institusional diformulasikan sebagai berikut :



\section{Komisaris Independen}

Anggota dewan komisaris yang tidak memiliki hubungan keuangan, hubungan kepengurusan, hubungan kepemilikan saham, dan/atau hubungan keluarga lainnya dengan anggota dewan komisaris lainnya, direksi dan/atau pemegang saham pengendali atau hubungan dengan bank, yang dapat mempengaruhi kemampuannya untuk bertindak independen. Proporsi komisaris independen diformulasikan sebagai berikut:

$$
\text { Konisaris Independen }=\frac{\text { Jumlah anggota konisaris independen }}{\text { Jumlah seluruh anggota komisaris }}
$$

\section{Intellectual Capital}

Intellectual Capital (Modal Intelektual) adalah berbagai macam sumber daya yang bersifat intangible asset baik berupa pengetahuan, informasi, keterampilan, properti intelektual, pengalaman, maupun sumber daya lainnya yang dapat digunakan oleh perusahaan untuk mendapatkan keuntungan atau manfaat lainnya dalam rangka mencapai tujuan. Metode yang telah dikembangkan oleh Pulic dalam (Ningrum, 2012a), Value Added Intellectual Capital Coefficient (VAIC TM) digunakan sebagai alat untuk mengukur kinerja modal intelektual perusahaan. Berdasar metode tersebut, pengukuran modal intelektual dalam penelitian ini menggunakan metode VAIC ${ }^{\text {TM}}$, yang terdiri dari physical capital/capital employed (VACA), human capital (VAHU) dan structural capital (STVA).

Sebelum menghitung variabel model intelektual secara keseluruhan, model ini harus dimulai dengan penghitungan value added (VA). Value added merupakan indikator yang paling obyektif 
untuk menunjukkan kemampuan perusahaan dalam penciptaan nilai Ihyaul Ulum (2009). Rumus

VA adalah : $V A=O U T-I N$

Keterangan :

$\mathrm{VA}=$ Value Added

OUT $=$ Output : total penjualan dan pendapatan lain

$\mathrm{IN}=$ Input : beban penjualan dan biaya-biaya lain kecuali gaji dan tunjangan karyawan

Metode VAIC mengukur efisiensi tiga jenis input perusahaan: modal manusia, modal struktural serta modal fisik dan finansial. Tahap setelah menghitung VA adalah menghitung komponen dari VAIC ${ }^{\text {TM }}$.

Setelah menghitung masing-masing komponen VAIC maka langkah terakhir yaitu penjumlahan seluruh komponen Intellectual Capital yaitu Value Added Intellectual Coefficient $(\mathrm{VAICTM}):$ VAIC $=V A C A+V A H U+S T V A$

\subsection{Teknik Analisis Data}

Metode analisis yang digunakan dalam penelitian ini adalah metode analisis data kuantitatif dengan menggunakan program SPSS 16 sebagai alat untuk menguji data tersebut. Analisis regresi berganda digunakan untuk menguji pengaruh Kepemilikan Manajerial, Kepemilikan Institusional, Komisaris Independen dan Intellectual Capital terhadap kinerja keuangan perusahaan manufaktur yang terdaftar di BEI. Pengujian regresi berganda dilakukan setelah model dari penelitian ini memenuhi syarat uji asumsi klasik.

Setelah persyaratan regresi linear berganda dari uji asumsi klasik terpenuhi maka pengujian regresi linear berganda dapat dilakukan. Adapun model persamaan regresi linier berganda dalam penelitian ini adalah sebagai berikut:

$$
\mathrm{Y}=\alpha+\beta 1 \mathrm{X} 1+\beta 2 \mathrm{X} 2+\beta 3 \mathrm{X3}+\beta 4 \mathrm{X} 4+\mathrm{e}
$$

Dimana :

$\mathrm{Y}=\mathrm{ROA}$ (return on asset)

$\mathrm{X} 1=$ kepemilikan institusional

$\mathrm{X} 2=$ Kepemilikan manajerial

$\mathrm{X} 3=$ komisaris independen

$\mathrm{X} 4$ = Intellectual Capital (VAIC)

$\alpha=$ konstanta

$\beta 1, \beta 2, \beta 3, \beta 4=$ koefisien variable

$\mathrm{e}=$ error

\section{HASIL PENELITIAN DAN PEMBAHASAN}

\subsection{Deskriptif Objek Penelitian}

Penelitian ini bertujuan menganalisis pengaruh good corporate governance, dan intellectual capital terhadap financial performance. Objek penelitian yang digunakan dalam penelitian ini adalah laporan tahunan dan laporan keuangan perusahaan manufaktur yang terdaftar di Bursa Efek Indonesia (BEI) untuk periode tahun 2014-2016. Jumlah populasi awal yang akan diteliti sebanyak 144 perusahaan. Dimana hasil proses pengumpulan data yang telah dilakukan penulis, maka diperoleh 72 sampel. Distribusi pengambilan sampel penelitian ini yakni sebagai berikut: 


\section{Tabel 1}

Pemilihan Sampel Penelitian

\begin{tabular}{|c|c|c|c|}
\hline Langkah & Keterangan & $\begin{array}{c}\text { Jumlah } \\
\text { Perusahaan }\end{array}$ & Total \\
\hline 1 & $\begin{array}{l}\text { Perusahaan manufaktur yang terdaftar di } \\
\text { Bursa Efek Indonesia periode 2014- } \\
2016\end{array}$ & $144 \times 3$ & 432 \\
\hline 2 & $\begin{array}{l}\text { Perusahaan yang tidak menerbitkan } \\
\text { laporan tahuman dan laporan keuangan } \\
\text { secara berturut-turut periode 2014-2016 }\end{array}$ & $19 \times 3$ & (57) \\
\hline 3 & $\begin{array}{l}\text { Perusahaan mamufaktur yang tidak } \\
\text { menggunakan mata uang rupiah periode } \\
2014-2016\end{array}$ & $28 \times 3$ & (84) \\
\hline 4 & $\begin{array}{l}\text { Perusahaan manufaktur yang mengalami } \\
\text { rugi periode 2014-2016 }\end{array}$ & $37 \times 3$ & (111) \\
\hline 5 & $\begin{array}{l}\text { Sampel perusahaan manufaktur yang } \\
\text { tidak memiliki kelengkapan data terkait } \\
\text { penelitian yang dilakukan. }\end{array}$ & 100 & $(100)$ \\
\hline 6 & Data outlier & 8 & (8) \\
\hline \multicolumn{3}{|c|}{ Total Sampel } & 72 \\
\hline
\end{tabular}

\subsection{Statistik Deskriptif}

Analisis statistik deskriptif merupakan analisis kualitatif yang akan membahas sebaran data yang meliputi rata-rata atau mean dan standar deviasi. Nilai minimun dan maksimum menunjukkan nilai terendah dan tertinggi dari variabel yang diteliti. kemudian nilai rata-rata dari variabel yang diteliti ditunjukkan oleh mean sedangkan sebaran data penelitian ditunjukkan oleh nilai standar deviasi.

Pada penelitian ini, digunakan 72 sampel penelitian. Sampel tersebut merupakan perusahaan manufaktur yang terdaftar di Bursa Efek Indonesia (BEI) berdasarkan hasil purposive sampling, di mana perusahaan manufaktur tersebut memiliki laporan tahunan dan laporan keuangan yang lengkap dari tahun 2014-2016 dan khususnya memiliki kelengkapan data yang digunakan sebagai variabel penelitian.

Tabel 2

Statistik Deskriptif

\begin{tabular}{|l|r|r|r|r|r|}
\hline & $\mathrm{N}$ & Minimum & Maximum & Mean & Std. Deviation \\
\hline ROA & 72 & .00 & .26 & .0681 & .05351 \\
KM & 72 & .00 & .32 & .0865 & .10741 \\
INST & 72 & .22 & .96 & .6212 & .18144 \\
INDP & 72 & .25 & .67 & .3860 & .08432 \\
IC & 72 & 1.48 & 66,25 & 23.3024 & 13.17124 \\
Valid N (listwise) & 72 & & & & \\
\hline
\end{tabular}

Berdasarkan table diatas, diketahui terdapat 5 variabel penelitian, yaitu :

$\begin{array}{ll}\text { ROA } & \text { : Retum On Asset } \\ \mathrm{KM} & \text { : Kepemilikan Manajerial } \\ \text { K.INST } & \text { : Kepemilikan Institusional } \\ \text { K.INDP } & \text { : Komisaris Independen } \\ \text { IC } & \text { : Intellectual Capital }\end{array}$

Sumber: Data Olah Penulis (2018) 
Berdasarkan tabel hasil statistik deskriptif tersebut maka berikut ini keterangan tiap-tiap variabel penelitian, yaitu :

Return on asset merupakan pengukuran kinerja keuangan, yaitu laba bersih dibagi dengan nilai total aset. Pengolahan data mentah dari penelitian ini dapat dilihat sebagaimana diringkas pada tabel 2 di atas menunjukkan bahwa jumlah sampel atau $\mathrm{N}$ data valid yang diteliti adalah sebanyak 72 sampel dari tahun 2014-2016. Dari hasil pengujian statistik deskriptif rata-rata ROA perusahaan manufaktur yang terdaftar di BEI pada tahun 2014-2016 adalah 0,0681 dengan standar deviasi 0,05351. Dimana ROA terendah adalah 0,00 dan tertinggi adalah 0,26.

Kepemilikan manajerial merupakan kepemilikan saham perusahaan oleh manajemen. Kepemilikan manajerial ini diukur dengan pembagian antara jumlah saham yang dimiliki manajer dibagi dengan jumlah saham yang beredar. Dari hasil pengujian statistik deskriptif rata-rata kepemilikan manajerial perusahaan manufaktur yang terdaftar di BEI pada tahun 2014-2016 adalah 0,0865 dengan standar deviasi 0,10741. Dimana kepemilikan manajerial terendah adalah 0,00 dan tertinggi adalah 0,32 .

Kepemilikan institusional merupakan kepemilikan saham perusahaan oleh institusi. Kepemilikan institusional ini diukur dengan pembagian antara jumlah saham yang dimiliki institusi dibagi dengan jumlah saham yang beredar. Dari hasil pengujian statistik deskriptif rata-rata kepemilikan institusional perusahaan manufaktur yang terdaftar di BEI pada tahun 2014-2016 adalah 0,6212 dengan standar deviasi 0,18144. Dimana kepemilikan Institusional terendah adalah 0,22 dan tertinggi adalah 0,96 .

Komisaris independen merupakan kepemilikan saham perusahaan oleh institusi. Kepemilikan institusional ini diukur dengan pembagian antara jumlah saham yang dimiliki institusi dibagi dengan jumlah saham yang beredar. Dari hasil pengujian statistik deskriptif rata-rata kepemilikan institusional perusahaan manufaktur yang terdaftar di BEI pada tahun 2014-2016 adalah 0,6212 dengan standar deviasi 0,18144. Dimana kepemilikan Institusional terendah adalah 0,22 dan tertinggi adalah 0,96 .

Intellectual capital (modal intelektual) merupakat asset tak berwujud baik berupa pengetahuan, informasi, keterampilan, properti intelektual, pengalaman, maupun sumber daya lainnya yang dapat digunakan oleh perusahaan untuk mendapatkan keuntungan atau manfaat lainnya dalam rangka mencapai tujuan. Variabel ini diukur dengan rumus VAIC, dari hasil pengujian statistik deskriptif rata-rata intellectual capital perusahaan manufaktur yang terdaftar di BEI pada tahun 2014-2016 adalah 23,3024. Hal ini berarti bahwa perusahaan sampel telah mengalokasikan dana untuk modal intelektual baik untuk modal fisik, modal SDM dan modal structural rata-rata sebesar 23,3024\%. Dengan standar deviasi 13,17124. Dimana nilai VAIC terendah adalah 1,48 dan tertinggi adalah 66,25 .

\subsection{Analisis Data}

\subsubsection{Uji Koefisien Determinasi $\left(R^{2}\right)$}

Koifisien determinasi mengukur seberapa jauh kemampuan model dalam menerangkan variasi dalam variabel dependen (Ghozali, 2016). Nilai R2 berkisar antara 0 sampai 1, bila R2 $\geq 0$ berarti tidak ada hubungan antara variabel independen dengan variabel dependen, sedangkan jika R2 $\leq 1$ berarti ada suatu hubungan yang sempurna atau dapat dikatakan bahwa variabel-variabel independen memberikan hampir semua informasi yang dibutuhkan untuk memprediksi variasi variabel dependen. Hasil uji koifisien determinasi dari keseluruhan perusahaan dapat dilihat pada tabel berikut: 


\section{Tabel 3}

Model Summary ${ }^{\mathrm{b}}$
\begin{tabular}{|l|r|r|r|l|}
\hline Model & \multicolumn{1}{|c|}{ R } & R Square & Adjusted R Square & $\begin{array}{c}\text { Std. Enror of the } \\
\text { Estimate }\end{array}$ \\
\hline 1 & $.594^{2}$ & .353 & .303 & 08467 \\
\hline
\end{tabular}

a. Predictors: (Constant), LAG_Y, KM, IC, INDP, INST

b. Dependent Vanable: ROA

\section{Sumber: Data Olah Penulis (2018)}

Berdasarkan tabel 3 diatas angka koefisien korelasi (R) menunjukan nilai sebesar 0,594 yang menandakan bahwa hubungan antara variabel independen dengan variabel dependen adalah kuat karena memiliki nilai $\mathrm{R}>0.05$.

Pada model summary besarnya nilai R2 untuk pengujian keseluruhan perusahaan adalah 0,303 dilihat pada kolom Adjusted $R$ Square. Hal ini berarti bahwa kemampuan variabel independen Kepemilikan Manajerial, Kepemilikan Institusional, Komisaris Independen, dan Intellectual Capital dalam menjelaskan variabel dependen sebesar 30\% sedangkan sisanya $(100 \%-30 \%=70 \%)$ dijelaskan oleh variabel- variabel lain di luar model yang tidak dimasukan dalam penelitian yang mungkin dapat mempengaruhi financial performance (kinerja keuangan).

\subsubsection{Uji F}

Uji statistik F menunjukkan apakah semua variabel independen yang dimasukkan kedalam model regresi mempunyai pengaruh secara bersama-sama (simultan) terhadap variabel dependen.

Dalam penelitian ini menggunakan taraf signifikansi 5\% $(0,05)$, sehingga jika nilai probabilitas $\leq 0,05$, maka dapat dikatakan terdapat pengaruh yang signifikan secara bersama-sama antara variabel bebas terhadap variabel terikat. Namun, jika nilai signifikansi $\geq 0,05$ maka tidak terdapat pengaruh yang signifikan secara bersama-sama antara variabel bebas terhadap variabel terikat. Hasil uji F dapat dilihat pada tabel berikut ini:

\section{Tabel 4}

\begin{tabular}{|c|c|c|c|c|c|c|}
\hline \multicolumn{7}{|c|}{$\begin{array}{c}\text { UjiF } \\
\text { ANOVA }^{b}\end{array}$} \\
\hline Model & & Sum of Squares & $d f$ & Mean Square & $F$ & Sig. \\
\hline 1 & Regression & 254 & 5 & .051 & 7.080 & $.000^{\circ}$ \\
\hline & Residual & 466 & 65 & .007 & & \\
\hline & Total & .720 & 70 & & & \\
\hline
\end{tabular}

\section{Sumber: Data Olah Penulis (2018)}

Dari hasil uji ANOVA atau uji $\mathrm{F}$ yang ditunjukkan dalam tabel 4.10, terlihat bahwa nilai probabilitas sebesar 0,000. Karena nilai probabilitas lebih kecil dari 0,05, maka dapat disimpulkan bahwa variabel kepemilikan manajerial, kepemilikan institusional, komisaris independen dan intellectual capital secara bersama-sama berpengaruh signifikan terhadap kinerja keuangan. 


\subsubsection{Uji T}

Uji statistik t pada dasarnya menunjukkan seberapa jauh pengaruh satu variabel independen secara individual (parsial) dalam menerangkan variasi variabel dependen (Ghozali, 2016). Uji t dapat dilakukan dengan melihat nilai probabilitas. Untuk dapat menginterprestasikan koifisien variabel independen, pada penelitian ini digunakan nilai unstandardized coefficient.

Uji $\mathrm{T}$ dilihat dengan probabilitas nilai $\mathrm{t}$ atau signifikansi $<0,05$, maka dapat dikatakan bahwa terdapat pengaruh antara variabel bebas terhadap variabel terikat secara parsial. Namun, jika probabilitas nilai t atau signifikansi $>0,05$, maka dapat dikatakan bahwa tidak terdapat pengaruh yang signifikan antara masing-masing variabel bebas terhadap variabel terikat. Hasil uji $\mathrm{T}$ dapat dilihat pada tabel berikut:

\section{Tabel 5}

Uji T

\begin{tabular}{|c|c|c|c|c|c|c|}
\hline \multirow{2}{*}{\multicolumn{2}{|c|}{ Model }} & \multicolumn{2}{|c|}{$\begin{array}{l}\text { Unstandardized } \\
\text { Coefficients }\end{array}$} & \multirow{2}{*}{$\begin{array}{l}\text { Standardize } \\
\text { d } \\
\text { Coefficient } \\
\text { s } \\
\text { Beta }\end{array}$} & \multirow[t]{2}{*}{$\mathrm{t}$} & \multirow[t]{2}{*}{ Sig. } \\
\hline & & $\mathrm{B}$ & Std. Error & & & \\
\hline \multirow[t]{5}{*}{1} & $\begin{array}{l}\text { (Constan } \\
\text { t) }\end{array}$ & .353 & .140 & & 2.523 & .014 \\
\hline & $\mathrm{K} \mathrm{M}$ & .026 & .063 & .051 & 411 & .682 \\
\hline & INST & -.173 & .106 & -.206 & -1.634 & .107 \\
\hline & INDP & -.277 & .177 & -.176 & -1.565 & .122 \\
\hline & $\mathrm{IC}$ & .019 & .008 & 264 & 2.506 & .015 \\
\hline
\end{tabular}

\section{Sumber: Data Olah Penulis (2018)}

Berdasarkan tabel 5 menunjukkan bahwa dari keempat variabel independen yang dimasukkan ke dalam model regresi, terlihat variabel IC yang signifikan, sementara variabel independen KM, INST, INDP tidak signifikan terhadap kinerja keuangan. Hal ini dapat dilihat dari nilai probabilitas dari IC sebesar 0,015, sementara KM sebesar 0,682, INST sebesar 0,107, INDP sebesar 0,122. Dari nilai variabel-variabel tersebut, ada tiga variabel yaitu KM, INST, dan INDP yang jauh diatas 0,05 (5\%). Dengan melihat hasil analisis data unstandardized coefficient pada tabel 5 maka diperoleh persamaan model regresi sebagai berikut :

$$
\begin{aligned}
& \mathrm{Y}=\alpha+\beta 1 \mathrm{X} 1+\beta 2 \mathrm{X} 2+\beta 3 \mathrm{X} 3+\beta 4 \mathrm{X} 4+\mathrm{e} \\
& =0,353+0,026-0,173-0,277+0,019+\mathrm{e}
\end{aligned}
$$

\subsection{Pembahasan Hipotesis}

\subsubsection{Pengaruh Kepemilikan Manajerian Terhadap Kinerja Keuangan}

Dari hasil analisis regresi yang ditunjukkan pada tabel 5 diketahui nilai koefisien regresi variabel kepemilikan manajerial sebesar 0,026 dan nilai signifikansi sebesar 0,682. Hal ini menunjukkan bahwa nilai signifikansi lebih dari 0,05 (5\%). Ini berarti dapat disimpulkan bahwa hipotesis pertama (H1), kepemilikan manajerial berpengaruh signifikan terhadap kinerja keuangan, ditolak. Dengan demikian, dapat diketahui bahwa kepemilikan manajerial tidak berpengaruh terhadap financial performance (kinerja keuangan). Hasil penelitian ini tidak sejalan dengan penelitian yang dilakukan oleh Ratnasari et al., (2016) yang membuktikan bahwa kepemilikan manajerial berpengaruh signifikan terhadap return on asset (kinerja keuangan). Namun hasil penelitian ini sejalan dengan beberapa penelitian yang dilakukan oleh Noviawan \& Septiani, (2013) yang menyatakan bahwa kepemilikan manajerial tidak berpengaruh terhadap kinerja keuangan yang diproksi dengan return on asset. 
Hal ini kemungkinan disebabkan karena kepemilikan manajerial yang dimiliki perusahaan sampel masih sangat sedikit. Dimana hal ini terlihat dari analisis statistik yang menunjukan sebagian besar perusahaan tidak memberikan kepemilikan saham kepada manajemennya. Dengan demikian, penyelarasan kepentingan pemegang saham dan agen kurang dapat terwujud. Kepemilikan manajerial pada level yang rendah menyebabkan manajer kurang maksimal dalam menjalankan tugasnya untuk memaksimalkan kekayaan pemegang saham yaitu meningkatan kinerja perusahaan dengan ROA, serta berusaha mengalihkan sumber daya perusahaan untuk kepentingan mereka sendiri. Hal ini dikarenakan, manajer tidak seutuhnya mendapat keuntungan yang diperoleh, tetapi mereka juga menanggung biaya yang dikeluarkan untuk meningkatkan keuntungan perusahaan. Jika manajemen memiliki seluruh atau sebagian saham perusahaan maka hal ini akan mempengaruhi manajemen dalam menjalankan perusahaan. Manajemen akan lebih termotivasi karena mempunyai kepentingan dan rasa memiliki dalam perusahaan sehingga hal ini akan meningkatkan kinerja.

\subsubsection{Pengaruh Kepemilikan Institusional Terhadap Kinerja Keuangan}

Dari hasil analisis regresi yang ditunjukkan pada tabel 5 diketahui nilai koefisien regresi variabel kepemilikan institusional sebesar -0,173 dan nilai signifikansi sebesar 0,107. Hal ini menunjukkan bahwa nilai signifikansi lebih dari 0,05 (5\%). Ini berarti dapat disimpulkan bahwa hipotesis kedua (H2), kepemilikan institusional berpengaruh signifikan terhadap kinerja keuangan, ditolak. Dengan demikian, dapat diketahui bahwa kepemilikan institusional tidak berpengaruh terhadap financial performance (kinerja keuangan). Hasil penelitian ini tidak sejalan dengan penelitian yang dilakukan oleh Kartikasari, (2016) yang membuktikan bahwa kepemilikan institusional berpengaruh signifikan terhadap kinerja keuangan.

Namun hasil penelitian ini sejalan dengan penelitian yang dilakukan oleh Ratnasari et al., (2016) yang menyatakan bahwa kepemilikan institusional tidak berpengaruh terhadap kinerja keuangan. Artinya jumlah pemegang saham institusi pada perusahaan sampel tidak mempengaruhi hasil kinerja. Kepemilikan saham oleh institusi-institusi lain akan mendorong peningkatan pengawasan yang lebih optimal, apabila institusional merasa tidak puas dengan kinerja manajerial, maka mereka akan menjual sahamnya kepasar. Perubahan perilaku institusional dari pasif menjadi aktif dapat meningkatkan akuntabilitas manajerial sehingga manajer akan bertindak lebih hati-hati dalam menjalankan aktifitas perusahaan.

Hal ini juga kemungkinan disebabkan karena kepemilikan institusional kurang memiliki kemampuan untuk memonitor atau mengontrol tindakan manajemen dalam memanfaatkan aset perusahaan secara efisien dan mencegah pemborosan. Kepemilikan institusional menjadikan manajer terikat dengan sebuah target yang diinginkan oleh investor dalam memperoleh laba sehingga manajer besar kemungkinan akan melakukan tindakan manipulasi sehingga tidak mampu mendorong peningkatkan kinerja keuangan. Adanya asimetri informasi antara manajer dan pihak pemegang saham menyebabkan manajer selaku pengelola perusahaan bisa mengendalikan perusahaan karena memiliki informasi lebih mengenai perusahaan dibandingkan pemegang saham. Sehingga adanya kepemilikan institusi tidak menjamin monitoring kinerja manajer dapat berjalan efektif.

\subsubsection{Pengaruh Komisaris Independen Terhadap Kinerja Keuangan}

Dari hasil analisis regresi yang ditunjukkan pada tabel 5 diketahui nilai koefisien regresi variabel dewan komisaris independen sebesar $-0,277$ dan nilai signifikansi 0,122 . Hal tersebut menunjukkan bahwa nilai signifikansi lebih besar dari 0,05 (5\%). Sehingga dapat disimpulkan bahwa hipotesis ketiga (H3), Komisaris Independen berpengaruh signifikan terhadap kinerja keuangan, ditolak. Hasil penelitian ini berbeda dengan penelitian terdahulu yang dilakukan oleh El-chaarani, 
(2014) yang membuktikan bahwa proporsi dewan komisaris independen berpengaruh signifikan terhadap kinerja keuangan. Namun penelitian ini sejalan dengan penelitian yang dilakukan oleh Noviawan \& Septiani (2013). Adanya komisaris independen dapat meningkatkan kualitas fungsi pengawasan dalam perusahaan, meskipun rata-rata proporsi komisaris independen dalam penelitian ini adalah 38\%, akan tetapi hal ini tetap tidak mempengaruhi kinerja perusahaan. Hal ini mungkin disebabkan karena komisaris independen yang terlibat dalam pengambilan keputusan kalah suara dengan anggota dewan komisaris lainnya sehingga kualitas fungsi pengawasan dalam perusahaan akan sulit ditingkatkan dan mengganggu peningkatan kinerja keuangan perusahaan.

\subsubsection{Pengaruh Intellectual Capital Terhadap Kinerja Keuangan}

Dari hasil analisis regresi yang ditunjukkan pada tabel 5 diketahui nilai koefisien regresi variabel intellectual capital sebesar 0,019 dan nilai signifikansi 0,015. Hal tersebut menunjukkan bahwa nilai signifikansi lebih kecil dari 0,05 (5\%). Sehingga dapat disimpulkan bahwa hipotesis keempat (H4), intellectual capital berpengaruh signifikan terhadap kinerja keuangan, diterima. Hasil penelitian ini sejalan dengan penelitian yang dilakukan oleh Widiatmoko (2015) yang membuktikan bahwa intellectual capital berpengaruh signifikan terhadap return on asset (kinerja keuangan). Berdasarkan hasil penelitian diatas maka dapat disimpulkan bahwa semakin besar intellectual capital maka semakin meningkat pula kinerja keuangan.

Artinya keuntungan atas seluruh aset yang dimiliki perusahaan akan semakin meningkat apabila perusahaan dapat memaksimalkan kinerja intellectual capital. Perusahaan sampel dalam penelitian ini telah memanfaatkan modal intelektual dengan baik, sehingga mampu mempengaruhi kinerja keuangan. Sejalan dengan Resources based theory, semakin baik pemanfaatan modal intelektual oleh perusahaan maka dapat menambah nilai suatu perusahaan serta dapat meningkatkan kinerja yang semakin baik pula dalam perusahaan yang kemudian berimbas pada pemuasan kepentingan yang dimiliki oleh para stakeholder perusahaan. Alokasi dana yang besar untuk pembiayaan modal intelektual untuk meningkatkan sumber daya manusianya, struktural dan sumber daya fisik lainnya dapat meningkatkan kualitas produksi secara umum yang pada akhirnya dapat meningkatkan profitabilitas perusahaan.

\section{PENUTUP}

\subsection{Kesimpulan}

Penelitian ini bertujuan untuk meneliti pengaruh good corporate governance yang terdiri dari kepemilikan manajerial, kepemilikan institusional dan komisaris independen, dan intellectual capital terhadap kinerja keuangan pada perusahaan manufaktur yang terdaftar di Bursa Efek Indonesia tahun 2014-2016. Berdasarkan hasil dari penelitian yang telah dilakukan, maka dapat diambil kesimpulan sebagai berikut :

1. Kepemilikan manajerial tidak berpengaruh terhadap kinerja keuangan.

2. Kepemilikan institusional tidak berpengaruh terhadap kinerja keuangan.

3. Dewan komisaris independen tidak berpengaruh terhadap kinerja keuangan.

4. Intellectual capital berpengaruh terhadap kinerja keuangan.

\subsection{Keterbatasan Penelitian}

Keterbatasan penelitian ini adalah sebagai berikut:

1. Penelitian ini hanya dilakukan pada perusahaan yang bergerak di bidang manufaktur, sehingga hasil penelitian ini tidak menggambarkan keseluruhan perusahaan yang terdaftar di Bursa Efek Indonesia. 
2. Variabel independen yang digunakan dalam penelitian ini masih terbatas dalam menjelaskan kinerja keuangan, yakni hanya sebesar $30 \%$.

\subsection{Saran}

Saran dari penelitian ini sebagai berikut:

1. Objek penelitian selanjutnya dikembangkan, tidak hanya pada perusahaan manufaktur. Dengan demikian penelitian selanjutnya dapat melihat dampak dari setiap variabel yang digunakan secara lebih luas terhadap perusahaan yang terdaftar di Bursa Efek Indonesia.

2. Peneliti selanjutnya dapat menambahkan variabel independen lainnya seperti menambah mekanisme corporate governance (dewan komisaris, dewan direksi, dan komite audit). Dengan demikian nilai koefisien determinasi dapat lebih ditingkatkan, sehingga model penelitian selanjutnya akan menjadi lebih kompleks. 


\section{DAFTAR PUSTAKA}

Agustina, W., Yuniarta, G. A., \& Kadek, N. S. (2015). Pengaruh Intellectual Capital , Corporate Social Responsibility dan Good Corporate Governance Terhadap Kinerja Keuangan ( Studi Kasus Pada Perusahaan BUMN yang Terdaftar di BEI. Universitas Pendidikan Ganesha, 3(1), $1-11$.

Retrieved https://ejournal.undiksha.ac.id/index.php/S1ak/article/download/4726/3593

Andreawan, A. (2013). Analisis Intellectual Capital, Mekanisme Corporate Governance Dan Corporate Social Responsibility Terhadap Financial Performance. Naskah Publikasi Ilmiah, (Universitas Muhammadyah Surakarta), 1-15. Retrieved from http://eprints.ums.ac.id/25765/

Ariantini, I. G. A., Yuniarta, G. A., \& Sujana, E. (2017). Pengaruh Intellectual Capital, Corporate Socia Responsibility, dan Good Corporate Governance Terhadap Kinerja Perusahaan (Studi Kasus Pada Perusahaan Manufaktur Yang Terdaftar Di Bursa Efek Indonesia Tahun 20112015). Jurnal Akuntansi, 7(1), 1-11. Retrieved from https://ejournal.undiksha.ac.id/index.php/S1ak/article/download/9467/6051

El-chaarani, H. (2014). The impact of corporate governance on the performance of lebanese banks. Journal of Business and Finance Research, 8(5), 35-46. Retrieved from http://www.theibfr2.com/RePEc/ibf/ijbfre/ijbfr-v8n5-2014/IJBFR-V8N5-2014-4.pdf

Faza, M. F., \& Hidayah, E. (2014). Pengaruh Intellectual Capital terhadap Profitabilitas, Produktivitas, dan Nilai Perusahaan pada Perusahaan Perbankan yang Terdaftar di Bursa Efek Indonesia (BEI). Ekbisi, VIII(2), 186-199. Retrieved from http://ejournal.uinsuka.ac.id/syariah/Ekbisi/article/view/355

Gozali, A., \& Hatane, E. (2014). Pengaruh Intellectual Capital Terhadap Kinerja Keuangan dan Nilai Perusahaan Khususnya Di Industri Keuangan dan Industri Pertambangan Yang Terdaftar Di Bursa Efek Indonesia Tahun 2008-2012. Business Accounting Review, 2(1998), 208-217. Retrieved from http://publication.petra.ac.id/index.php/akuntansibisnis/article/download/2401/2181

Kartika, M., \& Hatane, E. S. (2011). pengaruh intellectual capital pada profitabilits perusahaan perbankan yang terdaftar di Bursa Efek Indonesia pada tahun 2007 - 2011. Business Accounting Review, 1(2), 14-25. Retrieved from http://publication.petra.ac.id/index.php/akuntansibisnis/article/download/491/428

Kartikasari, Y. D. (2016). Pengaruh Good Corporate Governance dan Modal Intelektual Terhadap Kinerja Keuangan Perusahaan. Skripsi Sarjana, (FE Universitas Negeri Yogyakarta). Retrieved from http://eprints.uny.ac.id/43095/1/SKRIPSI_Yohannita Dwi Kartikasari_12812141003.pdf

Linda, Manik, T., \& Ruwanti, S. (2014). Pengaruh Intellectual capital dan good corporate governance terhadap kinerja keuangan perusahaan, Fakultas E, 1-18. Retrieved from http://jurnal.umrah.ac.id/wp-content/uploads/gravity_forms/1-

ec61c9cb232a03a96d0947c6478e525e/2017/02/JURNAL-LINDA-120462201057.pdf

Murwaningsari, E. (2009). Hubungan Corporate Governance, Corporate Social Responsibilities dan Corporate Financial Performance dalam satu Continuum. JURNAL AKUNTANSI DAN KEUANGAN, $\quad 11($ No.1), 30-41. $\quad$ Retrieved from https://media.neliti.com/media/publications/76771-ID-none.pdf

Ningrum, N. R. (2012a). Analisis Pengaruh Intellectual Capital Dan Corporate Governance Terhadap Financial Performance. Diponegoro Journal of Accounting, 1(2), 1-15. Retrieved from https://ejournal3.undip.ac.id/index.php/accounting/article/download/591/593 
Ningrum, N. R. (2012b). Analisis Pengaruh Intellectual Capital dan Good Corporate Governance terhadap Financial Performance (Studi Empiris pada Perusahaan Keuangan yang terdaftar di BEI tahun 2009-2011). Skripsi, Fakultas E. Retrieved from http://eprints.undip.ac.id/36168/1/NINGRUM.pdf

Noviawan, R. A., \& Septiani, A. (2013). PENGARUH MEKANISME CORPORATE GOVERNANCE DAN STRUKTUR KEPEMILIKAN TERHADAP KINERJA KEUANGAN (Studi Kasus Pada Perusahaan Manufaktur yang Terdaftar di BEI). Diponegoro Journal of Accounting, 2, 1-10. Retrieved from https://ejournal3.undip.ac.id/index.php/accounting/article/view/3464/3394

Agustina, W., Yuniarta, G. A., \& Kadek, N. S. (2015). Pengaruh Intellectual Capital , Corporate Social Responsibility dan Good Corporate Governance Terhadap Kinerja Keuangan ( Studi Kasus Pada Perusahaan BUMN yang Terdaftar di BEI. Universitas Pendidikan Ganesha, 3(1), 1-11. $\quad$ Retrieved from https://ejournal.undiksha.ac.id/index.php/S1ak/article/download/4726/3593

Andreawan, A. (2013). Analisis Intellectual Capital, Mekanisme Corporate Governance Dan Corporate Social Responsibility Terhadap Financial Performance. Naskah Publikasi Ilmiah, (Universitas Muhammadyah Surakarta), 1-15. Retrieved from http://eprints.ums.ac.id/25765/

Ariantini, I. G. A., Yuniarta, G. A., \& Sujana, E. (2017). Pengaruh Intellectual Capital, Corporate Socia Responsibility, dan Good Corporate Governance Terhadap Kinerja Perusahaan (Studi Kasus Pada Perusahaan Manufaktur Yang Terdaftar Di Bursa Efek Indonesia Tahun 20112015). Jurnal Akuntansi, 7(1), 1-11. Retrieved from https://ejournal.undiksha.ac.id/index.php/S1ak/article/download/9467/6051

El-chaarani, H. (2014). The impact of corporate governance on the performance of lebanese banks. Journal of Business and Finance Research, 8(5), 35-46. Retrieved from http://www.theibfr2.com/RePEc/ibf/ijbfre/ijbfr-v8n5-2014/IJBFR-V8N5-2014-4.pdf

Faza, M. F., \& Hidayah, E. (2014). Pengaruh Intellectual Capital terhadap Profitabilitas, Produktivitas, dan Nilai Perusahaan pada Perusahaan Perbankan yang Terdaftar di Bursa Efek Indonesia (BEI). Ekbisi, VIII(2), 186-199. Retrieved from http://ejournal.uinsuka.ac.id/syariah/Ekbisi/article/view/355

Gozali, A., \& Hatane, E. (2014). Pengaruh Intellectual Capital Terhadap Kinerja Keuangan dan Nilai Perusahaan Khususnya Di Industri Keuangan dan Industri Pertambangan Yang Terdaftar Di Bursa Efek Indonesia Tahun 2008-2012. Business Accounting Review, 2(1998), 208-217. Retrieved from http://publication.petra.ac.id/index.php/akuntansibisnis/article/download/2401/2181

Kartika, M., \& Hatane, E. S. (2011). pengaruh intellectual capital pada profitabilits perusahaan perbankan yang terdaftar di Bursa Efek Indonesia pada tahun 2007 - 2011. Business Accounting Review, 1(2), 14-25. Retrieved from http://publication.petra.ac.id/index.php/akuntansibisnis/article/download/491/428

Kartikasari, Y. D. (2016). Pengaruh Good Corporate Governance dan Modal Intelektual Terhadap Kinerja Keuangan Perusahaan. Skripsi Sarjana, (FE Universitas Negeri Yogyakarta). Retrieved from http://eprints.uny.ac.id/43095/1/SKRIPSI_Yohannita Dwi Kartikasari_12812141003.pdf

Linda, Manik, T., \& Ruwanti, S. (2014). Pengaruh Intellectual capital dan good corporate governance terhadap kinerja keuangan perusahaan, Fakultas E, 1-18. Retrieved from http://jurnal.umrah.ac.id/wp-content/uploads/gravity_forms/1ec61c9cb232a03a96d0947c6478e525e/2017/02/JURNAL-LINDA-120462201057.pdf 
Murwaningsari, E. (2009). Hubungan Corporate Governance, Corporate Social Responsibilities dan Corporate Financial Performance dalam satu Continuum. JURNAL AKUNTANSI DAN KEUANGAN, 11(No.1), 30-41. Retrieved from https://media.neliti.com/media/publications/76771-ID-none.pdf

Ningrum, N. R. (2012a). Analisis Pengaruh Intellectual Capital Dan Corporate Governance Terhadap Financial Performance. Diponegoro Journal of Accounting, 1(2), 1-15. Retrieved from https://ejournal3.undip.ac.id/index.php/accounting/article/download/591/593

Ningrum, N. R. (2012b). Analisis Pengaruh Intellectual Capital dan Good Corporate Governance terhadap Financial Performance (Studi Empiris pada Perusahaan Keuangan yang terdaftar di BEI tahun 2009-2011). Skripsi, Fakultas E. Retrieved from http://eprints.undip.ac.id/36168/1/NINGRUM.pdf

Noviawan, R. A., \& Septiani, A. (2013). PENGARUH MEKANISME CORPORATE GOVERNANCE DAN STRUKTUR KEPEMILIKAN TERHADAP KINERJA KEUANGAN (Studi Kasus Pada Perusahaan Manufaktur yang Terdaftar di BEI). Diponegoro Journal of Accounting, 2, 1-10. from https://ejournal3.undip.ac.id/index.php/accounting/article/view/3464/3394

Pratama, I. W. G. S., \& Suputra, I. D. G. D. (2015). Pengaruh Good Corporate Governance Dan Intellectual Capital Pada Return on Asset. E-Jurnal Akuntansi Universitas Udayana, 2, 417425. Retrieved from https://ojs.unud.ac.id/index.php/Akuntansi/article/download/10148/8475

Ratnasari, R. B., Titisari, K. H., \& Suhendro. (2016). Pengaruh Value Added Intellectual Capital, GCG, Dan Struktur Kepemilikan Terhadap Kinerja Keuangan (Studi Kasus Pada Perusahaan Manufaktur yang Terdaftar di BEI). Journal of Economic and Economic Education, 4(2), 240 257. Retrieved from https://media.neliti.com/media/publications/54967-ID-pengaruh-valueadded-intellectual-capita.pdf

Sari, A. puspita, \& Priyadi, M. P. (2017). Pengaruh Intellectual Capital Dan Corporate Governance Terhadap Kinerja Perusahaan. Jurnal Ilmu Dan Riset Akuntansi, 6(2008), 1-20. Retrieved from https://ejournal.stiesia.ac.id/jira/article/download/3303/2819

Tertius, M. A., \& Christiawan, Y. J. (2015). Pengaruh Good Corporate Governance terhadap Kinerja Perusahaan pada Sektor Keuangan. Business Accounting Review, 3(1), 47-60. Retrieved from http://publication.petra.ac.id/index.php/akuntansi-bisnis/article/download/2763/2474

Ulum, I., Ghozali, \& A, C. (2008). Intellectual Capital Dan Kinerja Keuangan Perusahaan; Suatu Analisis Dengan Pendekatan Partial Least Squares. Seminar Nasional Akuntansi, 19(19), 23-24. Retrieved from http://eprints.undip.ac.id/17126/1/SNA11Ulum_Ghozali_Chariri.pdf

Undang-Undang No.40. (2007). Undang-Undang Republik Indonesia Nomor 40 Tahun 2007 Tentang Perseroan Terbatas, 1-189.

Wardhani, R. (2007). Mekanisme Corporate Governance Dalam Perusahaan yang mengalami permasalahan keuangan. Jurnal Akuntansi Dan Keuangan Indonesia, 4(No. 1), 95-114. https://doi.org/10.21002/jaki.2007.05

Widiatmoko, R. G. (2015). Pengaruh Intellectual Capital Terhadap Profitabilitas Perusahaan Manufaktur Yang Terdaftar Di Bursa Efek Indonesia. Skripsi Fakultas Ekonomi Universitas Negeri Yogyakarta. Retrieved from eprints.uny.ac.id/27539/1/15. FULL SKRIPSI.pdf

Wijaya, M. H. (2017). Pengaruh Intellectual Capital terhadap kinerja perusahaan otomotif di bursa efek Indonesia. Jurnal Ilmu \& Riset Akuntansi, 6(No. 1). Retrieved from https://ejournal.stiesia.ac.id/jira/article/download/2811/243 